\title{
POLA PENCEMARAN LOKASI PENANGKAPAN DAN IKAN HASIL TANGKAPAN AKIBAT BERKEMBANGNYA AKTIVITAS EKONOMI DI SEKITAR DANAU MANINJAU
}

\section{The Contamination Pattern of Fishing Ground and Fish Caught as Effect of Economic Activities around Maninjau Lake}

\author{
Mustaruddina $^{\mathrm{a}}$, Eko Sri Wiyono ${ }^{\mathrm{a}}$, Mohammad Khotib ${ }^{\mathrm{b}}$, Asnil ${ }^{\mathrm{c}}$, Samsul Bahri ${ }^{\mathrm{d}}$ \\ ${ }^{a}$ Departemen Pemanfaatan Sumberdaya Perikanan, Fakultas Perikanan dan Ilmu Kelautan, Institut Pertanian \\ Bogor, Kampus IPB Darmaga, Jalan Agatis, Bogor16680-mus_m03@yahoo.com \\ ${ }^{b}$ Departemen Kimia, Fakultas Matematika dan Ilmu Pengetahuan Alam, Institut Pertanian Bogor, Kampus IPB \\ Darmaga, Jalan Agatis, Bogor 16680 \\ ${ }^{c}$ Peneliti Lingkungan dan Urban, Kementerian Dalam Negeri, Jl. Medan Merdeka Utara No. 7, Jakarta \\ ${ }^{d}$ Peneliti Perikanan Lemkaspa, Jl. Babakan Raya No. 09, Bogorl6610 Jawa Barat
}

\begin{abstract}
Maninjau Lake is the territorial waters of which contribute greatly to fish production in Agam, West Sumatra. But a lot of waste of economic activities discharged into the lake. This study aims to analyze the characteristics of fishing, contamination status of fishing ground and fish caught, to analyze the contamination pattern of fishing ground and fish caught as effect of economic activity waste. The methods used are descriptive method, physic-chemical analysis, correlation method, and multiple regression method. The results showed the fishing in Lake Maninjau, generally using langli net, lift net, hook and lines, and cast net. While the main fish caught are nile tilapia, bada fish, rinuak fish, carp, and limbek fish. Fishing ground in Maninjau Lake contaminated by ammonia, garbage, Cd and $\mathrm{Hg}$ metals, while the fish caught, there was found to have gills dirty. Significantly, fishing ground disturbed by the waste of hydropower $\left(X_{1}\right)$, lake tourism $\left(X_{2}\right)$, settlements $\left(X_{4}\right)$, and KJA fisheries $\left(X_{5}\right)$. The contamination pattern of fishing ground formulated by $Y_{1}=0,220 X_{1}+0,085 X_{2}+0,227 X_{4}+0,204 X_{5}-4,540$. Fish production disturbed significantly by the waste from hotel and restaurants $\left(X_{3}\right)$, seattlements $\left(X_{4}\right)$, and KJA fisheries $\left(X_{5}\right)$. The contamination pattern of fish caught, represented by a decrease in fish production $\left(Y_{2}\right)$ formulated by $Y_{2}=1,195 X_{3}+2,152 X_{4}+5,140 X_{5}-41,664$.
\end{abstract}

Keywords: Contamination, fish caught, heavy metals, maninjau lake, fishing ground.

(Diterima: 21-02-2017; Disetujui: 13-09-2017)

\section{Pendahuluan}

Danau Maninjau merupakan wilayah perairan yang berkontribusi besar terhadap produksi ikan di Kabupaten Agam, Sumatera Barat. Danau ini memiliki luas 99,5 km² dan kedalaman maksimum sekitar $495 \mathrm{~m}$, dengan bentuk yang memanjang dari utara ke selatan (Suryono dan Lukman, 2016). Kegiatan perikanan yang berkembang di Danau Maninjau adalah penangkapan ikan dan budidaya perikanan keramba jaring apung (KJA). Dibandingkan dengan perikanan KJA yang berkembang tahun 1990-an, kegiatan penangkapan ikan telah berkembang lama sejak masyarakat Minang mendiami dataran tinggi Agam (Asnil et al., 2013; Said et al., 2011). Saat ini, kegiatan penangkapan ikan tersebut melibatkan 530 nelayan yang tersebar pada sembilan nagari/desa di sekitar Danau Maninjau. Sedangkan lokasi penangkapan utama berada di areal outlet (sebelah utara) dan areal inlet (sebelah selatan) dari danau.

Roesma (2013) menyatakan bahwa ada 53 jenis ikan air tawar yang hidup di Danau Maninjau, dan sebagian besar merupakan ikan target penangkapan. Beberapa target tangkapan tersebut merupakan jenis ikan endemik yang tidak bisa diusahakan dengan budidaya, namun menjadi ciri khas daerah. Ikan bada
(Rasbora argyrotaenia) dan ikan rinuak (Psylopsis sp.) misalnya, telah dikenal secara nasional sebagai produk perikanan Provinsi Sumatera Barat, khususnya Kabupaten Agam (Wargasasmita, 2002). Hal inilah yang menjadi penyebab kegiatan penangkapan ikan terus berkembang dan dilestarikan di Danau Maninjau. Namun demikian, masalah baru sering timbul dengan terus berkembangnya aktivitas ekonomi di kawasan Danau Maninjau dan sekitarnya. Aktivitas ekonomi tersebut, baik yang berskala industri maupun domestik telah menjadikan Danau Maninjau sebagai outlet dari limbah yang ditimbulkannya. Menurut Nontji (2016), perikanan KJA, pemukiman, dan pertanian sekitar danau merupakan sumber penghasil limbah padat dengan jumlah buangan ke Danau Maninjau masingmasing mencapai 393,22 ton/tahun, 7,55 ton/tahun, dan 5,08 ton/tahun. Hastings dan Ryan (2017) dan Pascoe et al. (2014) menambahkan bahwa kegiatan wisata danau (berenang, menyelam, dan berlayar) yang dilakukan secara tidak terkontrol juga dapat mengganggu pemanfaatan ruang dan mencemari areal perairan yang dilewatinya. Sebagian besar limbah tersebut merupakan komponen organik yang mudah busuk dan dapat mencemari perairan dalam areal yang luas. 
Kasus kematian ikan massal pada tahun 2009, 2010, 2011, dan 2016 di Danau Maninjau merupakan dampak nyata dari pencemaran tersebut (BP2KSI, 2016; Said et al., 2011). Menurut Fernández et al. (2013), selain ikan target penangkapan banyak yang mati seketika, pencemaran lokasi penangkapan ikan mempunyai dampak buruk yang jarang terekspos, yaitu kerusakan habitat dan terputusnya rantai makanan. Hal ini karena diatom, zooflankton, tumbuhan air, dan ikan-ikan kecil yang menjadi makanan bagi ikan target ikut tercemar dan mati. Dampak lanjutannya, populasi ikan target penangkapan terus merosot, bahkan untuk spesies tertentu bisa musnah. Bila hal ini dibiarkan, maka nelayan tradisional air tawar akan kehilangan mata pencaharian dan ikan hasil tangkapan yang menjadi ciri khas daerah hanya tinggal kenangan. Penelitian ini diharapkan dapat memberi informasi berarti untuk penanganan dampak pencemaran terhadap kegiatan penangkapan ikan di masa datang. Tujuan penelitian ini adalah: (1) menganalisis karakteristik penangkapan ikan, status pencemaran lokasi penangkapan dan ikan hasil tangkapan, serta (2) menganalisis pola pencemaran lokasi penangkapan dan ikan hasil tangkapan akibat limbah aktivitas ekonomi di sekitar Danau Maninjau.

\section{Metode}

\subsection{Tempat dan Waktu Penelitian}

Tempat penelitian adalah kawasan Danau Maninjau dan sekitarnya di Kabupaten Agam, Sumatera Barat. Sampling dilakukan di perairan sebelah utara dan sebelah selatan dari Danau Maninjau yang menjadi lokasi penangkapan ikan bagi nelayan setempat (Gambar 1). Penelitian ini dilakukan pada bulan Oktober 2015 - Februari 2016.

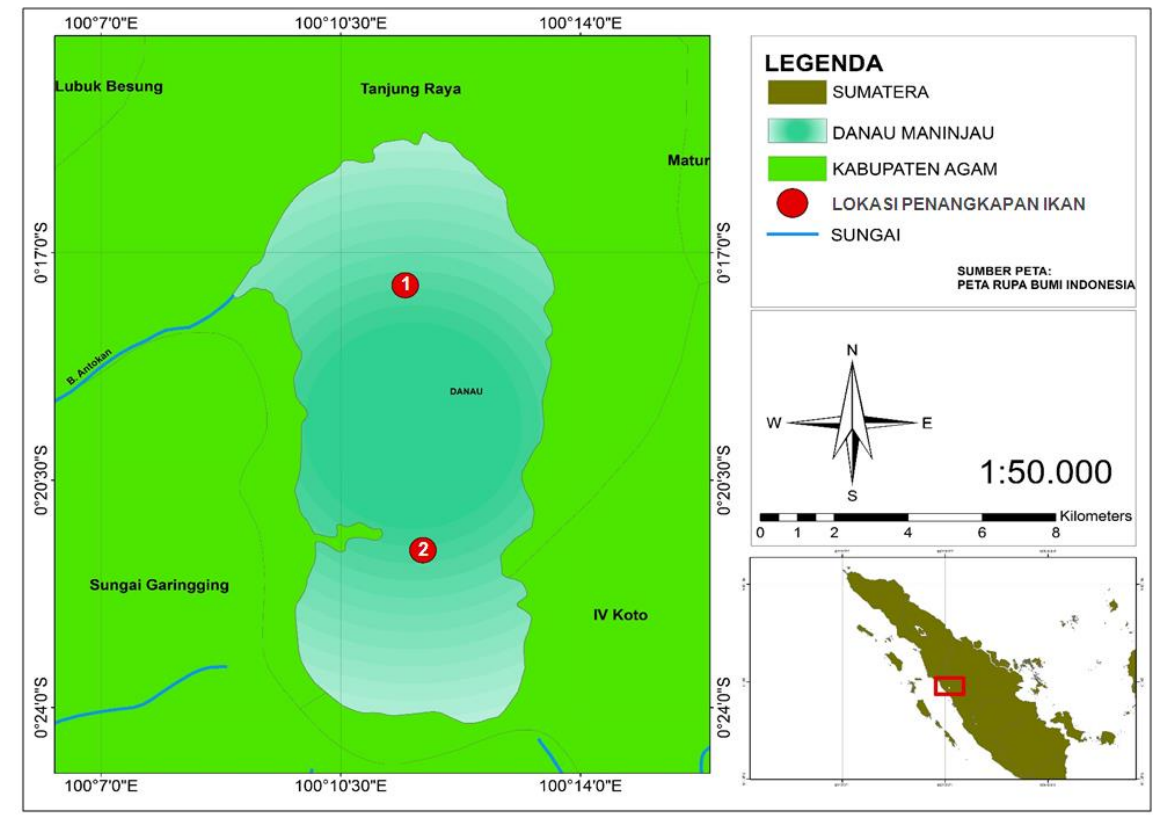

Gambar 1. Tempat penelitian

\subsection{Bahan dan Alat}

Bahan yang digunakan dalam penelitian ini terdiri dari kuesioner, sampel air, dan sampel ikan. Peralatan mencakup paket peralatan laboratorium, alat tulis, kalkulator, kamera, dan program aplikasi SPSS (Statistical Package for Social Sciences).

\subsection{Jenis Data dan Metode Pengumpulan Data}

Jenis data yang dikumpulkan dalam penelitian ini terdiri dari data primer dan data sekunder. Data primer mencakup data penangkapan ikan (alat tangkap dan ikan hasil tangkapan), karakteristik fisik dan kimia perairan ( $\mathrm{pH}, \mathrm{DO}$, amoniak, kebauan, sampah, deterjen, warna, suhu, logam $\mathrm{Cd}$ dan $\mathrm{Hg}$ ) perairan sekitar lokasi penangkapan ikan, serta data pencemaran lokasi penangkapan dan ikan hasil tangkapan akibat limbah suatu aktivitas ekonomi. Sedangkan data sekunder berupa profil perikanan tangkap serta hasil kajian lingkungan dan potensi perikanan Danau Maninjau.

Data karakteristik fisik dan kimia perairan dikumpulkan dengan mengambil sampel air pada dua titik/lokasi penangkapan ikan terpilih di Danau Maninjau (Gambar 1). Pengambilan sampel tersebut dilakukan dengan teknik grab sampling menggunakan botol gelap dengan pertimbangan kualitas air relatif stabil pada perairan danau yang tenang. Sampel ikan diambil dari jenis ikan yang tertangkap dominan di Danau Maninjau, yaitu ikan nila dan ikan bada. Jumlah sampel ikan untuk analisis logam berat masing-masing 4 ekor ( 2 ikan nila dan 2 ikan bada) untuk setiap lokasi penangkapan ikan. Sampel ikan untuk analisis organoleptik, kondisi insang, dan sisik berkisar 5-10\% dari jumlah ikan hasil tangkapan dalam satu trip penangkapan di setiap lokasi. Kisaran sampel tersebut 
mengacu kepada Fahrul (2007) tentang sampling bioekologi. Data karakteristik penangkapan ikan dikumpulkan melalui kuesioner. Responden untuk penangkapan ikan adalah nelayan pemilik/nakhoda dari alat tangkap yang banyak digunakan di Danau Maninjau. Jumlah responden untuk setiap jenis alat tangkap adalah 2 orang, dengan pertimbangan spesifikasi teknis alat tangkap tersebut cukup sederhana dan ikan hasil tangkapannya juga relatif sama. Data pencemaran lokasi penangkapan dan ikan hasil tangkapan dikumpulkan melalui kuesioner dan pengamatan langsung. Jumlah responden untuk pengisina kuesioner adalah 30 orang. Hal ini mengacu kepada ketentuan analisis linear majemuk yang mensyaratkan jumlah data minimal 25 ulangan (Field 2013; Fahrul 2007). Responden tersebut berasal perwakilan nelayan, penjual ikan, staf institusi perikanan, dan masyarakat.

Pemilihan responden untuk data karakteristik penangkapan, serta data pencemaran lokasi penangkapan dan ikan hasil tangkapan dilakukan secara purposive sampling. Hal ini supaya data dapat diperoleh dari pihak-pihak yang mengerti betul kondisi perikanan tangkap dan faktor-faktor yang mempengaruhinya (Field, 2013). Data sekunder dikumpulkan melalui telaah pustaka terhadap profil/laporan perikanan tangkap serta hasil kajian yang tersedia di Dinas Kelautan dan Perikanan, lembaga penelitian, dan perguruan tinggi.

\subsection{Metode Analisis}

Analisis data karakteristik penangkapan ikan dilakukan menggunakan metode deskriptif. Menurut Maina et al. (2016), metode deskriptif dapat menggambarkan dengan jelas kondisi subjek atau objek penelitian berdasarkan fakta-fakta kini yang tampak atau apa adanya. Hasil analisisnya kemudian disajikan dalam bentuk tabel, grafik atau gambar yang relevan.

Data sampel air di sekitar lokasi penangkapan ikan dan sampel ikan dianalisis secara laboratory. Parameter yang dianalisis untuk sampel air adalah parameter fisiko-kimia yang mencerminkan pencemaran suatu perairan yang menjadi lokasi penangkapan ikan. Parameter tersebut adalah $\mathrm{pH}$, dissolved oxygen (DO), amoniak $\left(\mathrm{NH}_{3}-\mathrm{N}\right)$, kebauan, sampah, deterjen, warna, suhu, logam $\mathrm{Cd}$, dan logam Hg (Maina et al., 2016; Fernández et al., 2013). Untuk sampel ikan, parameter yang dianalisis adalah logam $\mathrm{Cd}$, logam $\mathrm{Hg}$, kebauan, kekotoran insang, dan kelendiran sisik. Khusus untuk parameter kebauan, kekotoran insang, dan kelendiran sisik dianalisis secara organoleptik. Untuk mengetahui status pencemaran lokasi penangkapan dan ikan hasil tangkapan, maka hasil analisis diperbandingkan dengan kriteria mutu air kelas III (untuk perikanan) menurut Peraturan Pemerintah No. 82 Tahun 2001 dan batas maksimum cemaran logam berat dalam bahan pangan menurut Standar Nasional Indonesia 7387: 2009.

Pola pencemaran lokasi penangkapan dan ikan hasil tangkapan akibat limbah aktivitas ekonomi dianalisis menggunakan dua metode, yaitu metode korelasi dan metode multiple regression. Pengoperasian kedua metode tersebut menggunakan program SPSS. Metode korelasi digunakan untuk menganalisis seberapa jauh keterkaitan/interaksi lokasi penangkapan dan ikan hasil tangkapan dengan peningkatan limbah aktivitas ekonomi. Menurut Sarwono (2006), metode korelasi sangat membantu dalam analisis hubungan sebab akibat diantara komponen yang berinteraksi di alam nyata. Respon interaksi tersebut bisa searah/saling mendukung (korelasi positif) dan bisa tidak searah (korelasi negatif). Hasil analisis dari metode korelasi ditunjukkan oleh nilai pearson correlation (PC). Perhitungan nilai PC menggunakan rumus (Field, 2013):

$$
P C=\frac{N \sum X Y-\left(\sum X\right)\left(\sum Y\right)}{\sqrt{\left(N \sum X^{2}-\left(\sum X\right)^{2}\right)} \sqrt{\left(N \sum Y^{2}-\left(\sum Y\right)^{2}\right)}}
$$

Dimana:

$P C=$ nilai pearson correlation

$\sum X Y=$ total hasil perkalian nilai $\mathrm{X}$ dan nilai $\mathrm{Y}$

$\sum X=$ total nilai $X$

$\sum Y=$ total nilai $\mathrm{Y}$

$\sum X^{2}=$ total kuadrat nilai $X$

$\sum Y^{2}=$ total kuadrat nilai $\mathrm{Y}$

$X \quad=$ limbah aktivitas ekonomi (PLTA, wisata danau, hotel dan restoran, pemukiman, perikanan KJA, dan pertanian)

$Y=$ kegiatan penangkapan ikan (lokasi penangkapan dan ikan hasil tangkapan/produksi ikan)

$N \quad=$ jumlah sampel/ulangan

Uji statistik yang digunakan untuk menilai hasil analisis tersebut adalah uji keeratan dan uji probability (Field, 2013; Sarwono, 2006). Kategori keeratan (R) dibagi menjadi empat, yaitu: rendah (range PC: 0,000 0,250 ), sedang (range $\mathrm{PC}:>0,250$ - 0,500), kuat (range PC: > 0,500 - 0,750), dan sangat kuat (range PC: > 0,750-1,000). Uji probability (P) digunakan untuk mengukur tingkat signifikansi dari interaksi yang terjadi, dan dinyatakan signifikan atau berdampak serius bila mempunyai nilai $\mathrm{P}<0,05$.

Untuk interaksi yang mempunyai nilai $\mathrm{P}<0,05$, dianalisis lanjut menggunakan metode multiple regression untuk menentukan pola pencemaran yang ditimbulkannya. Ada dua jenis pola pencemaran yang dimaksud, yaitu: (a) pola pencemaran lokasi penangkapan ikan akibat limbah aktivitas ekonomi, dan (b) pola pencemaran ikan hasil tangkapan (diwakili oleh penurunan produksi ikan) akibat limbah aktivitas ekonomi. Pola pencemaran tersebut ditentukan menggunakan rumus multiple regression (Field, 2013):

$$
Y=a_{1} X_{1}+a_{2} X_{2}+a_{3} X_{3}+\ldots \ldots+a_{n} X_{n}+b
$$


Dimana:

$\begin{aligned} Y= & \text { pencemaran lokasi penangkapan ikan atau } \\ & \text { ikan hasil tangkapan (diwakili oleh } \\ & \text { penurunan produksi ikan) } \\ = & \text { koefisien dari } \mathrm{X} \\ = & \text { limbah aktivitas ekonomi yang mempu-nyai } \\ & \text { nilai } \mathrm{P}<0,05 \text { pada analisis korelasi } \\ X \quad & \text { konstanta }\end{aligned}$

Uji statistik yang digunakan untuk menilai hasil analisis regresi tersebut adalah analisis koefisien determinasi (R) dan uji probability model regresi (Field 2013). Nilai R digunakan untuk menunjukkan tingkat pengaruh dari kombinasi variabel $\mathrm{X}$ yang diakomodir terhadap variabel Y. Uji probability $(\mathrm{P})$ berguna untuk mengukur tingkat signifikansi/tingkat kepercayaan dari model regresi yang didapat, dan dinyatakan dapat dipercaya bila mempunyai nilai $\mathrm{P}<0,05$.

\section{Hasil dan Pembahasan}

\subsection{Karakteristik Penangkapan Ikan di Danau Maninjau}

Penangkapan ikan di Danau Maninjau merupakan salah satu kegiatan perikanan yang diperhitungkan di Kabupaten Agam, Sumatera Barat. Kegiatan ini melibatkan 530 nelayan yang bermukim pada sembilan nagari di sekitar Danau Maninjau. Alat tangkap yang digunakan diantaranya jaring langli, lukah, bagan bada, anco, jala, pancing, dan tubo (racun ikan) (Tabel 1).

Tabel 1. Karakteristik teknis alat tangkap di Danau Maninjau

\begin{tabular}{|c|c|c|c|c|}
\hline No & Alat tangkap & Jumlah ABK (Orang) & Ukuran Kapal (GT) & Lama Trip (hari) \\
\hline 1 & Jaring Langli & $2-3$ & $1-2$ & 1 \\
\hline 2 & Lukah & 1 & $<1$ & 1 \\
\hline 3 & Bagan Bada & $2-3$ & $1-2$ & $1-2$ \\
\hline 4 & Anco & $1-2$ & 1 & 1 \\
\hline 5 & Jala & 1 & $<1$ & 1 \\
\hline 6 & Pancing & 1 & $<1$ & 1 \\
\hline 7 & Tubo (racun ikan) & 1 & - & 1 \\
\hline
\end{tabular}

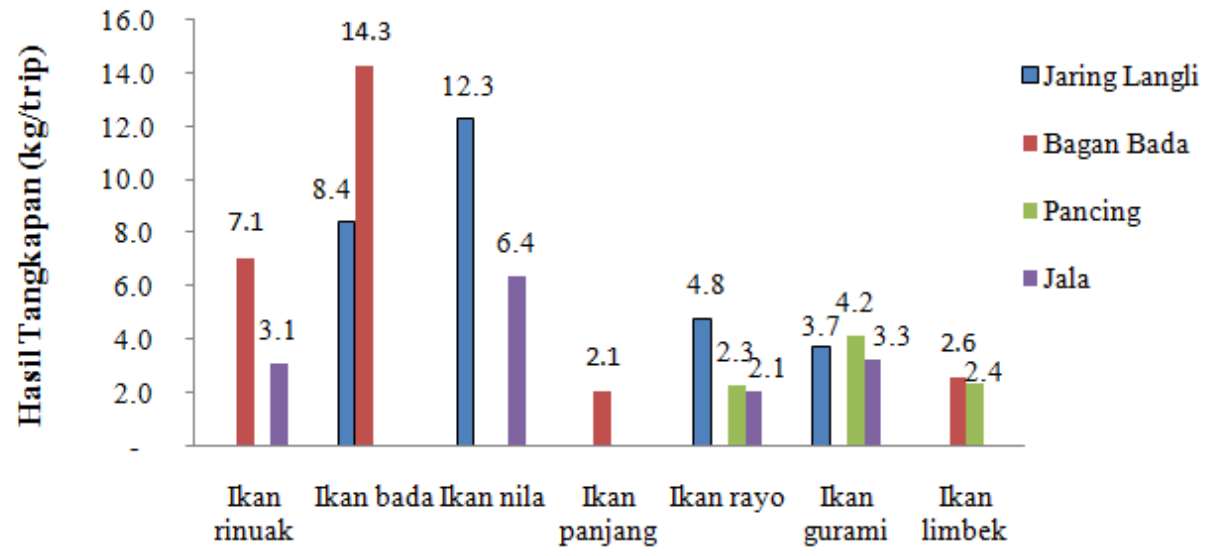

Jenis Ikan

Gambar 2. Komposisi ikan hasil tangkapan utama

Jaring langli adalah jaring insang atau gillnet dengan ukuran menengah, sedangkan lukah adalah perangkap berbentuk tabung yang terbuat dari bambu, dimana salah satu ujungnya didesain mengerucut. Bagan bada merupakan jenis bagan tancap ukuran sedang yang dipasang di areal danau yang agak dangkal. Lokasi pemasangan bagan bada ini mulai menyempit dan berpotensi tercemar dengan banyaknya penyebaran KJA di areal danau yang dangkal. Pemberian nama bagan ini mengacu kepada jenis ikan target, yaitu ikan bada yang merupakan jenis ikan endemik Danau Maninjau (Said et al., 2011; Wargasasmita, 2002). Ukuran alat tangkap di Danau Maninjau (Tabel 1) tidak terlalu besar, sehinga $\mathrm{ABK}$ yang terlibat dalam penangkapan hanya 1-3 orang dan kapal yang digunakan bisa di bawah 2 GT. Dari 7 (tujuh) alat tangkap tersebut, yang banyak digunakan saat ini hanya jaring langli, bagan bada, pancing, dan jala (DKP Kabupaten Agam, 2015). Gambar 2 menyajikan komposisi ikan hasil tangkapan utama dari keempat alat tangkap tersebut.

Berdasarkan Gambar 2, hasil tangkapan jaring langli terdiri dari ikan nila $12,3 \mathrm{~kg}(42,1 \%)$, ikan bada $8,4 \mathrm{~kg}(28,8 \%)$, ikan rayo/mas 4,8 kg (16,4\%), dan ikan gurami 3,7 kg (12,7\%). Zydelis et al. (2013) dan Gundo (2010) menyatakan bahwa komposisi hasil tangkapan gillnet dan sejenisnya sangat bergantung pada pilihan mesh size dari jaring yang digunakan. Bagan bada mempunyai hasil tangkapan utama berupa ikan bada $(54,8 \%)$ dan ikan rinuak $(27,2 \%$.). Ikan 
bada dan ikan rinuak merupakan hasil perikanan tradisional dari Danau Maninjau dan telah berlangsung sejak masyarakat Minang mendiami dataran tinggi Agam (Asnil et al. 2013; Said et al. 2011). Menurut Wargasasmita (2002), ikan bada dan ikan rinuak dikenal secara nasional sebagai produk perikanan khas Minang. Hasil tangkapan utama pancing berupa ikan gurami dan ikan limbek, sedangkan jala berupa ikan nila dan ikan gurami. Biasanya ikan limbek dan gurami banyak ditangkap di outlet Danau Maninjau, namun saat ini sudah berkurang karena koagulasi bahan pencemar yang meningkat (Suryono dan Lukman, 2016; Setiyawan et al., 2016). Ikan limbek lebih mudah ditangkap dengan pancing karena termasuk jenis ikan pemangsa dan lebih menyukai umpan hidup/segar seperti jangkrik, udang dan kecoa. Untuk ikan gurami juga dapat ditangkap dengan pancing berumpan, karena pada saat muda bersifat karnivora (Susanto, 1989). Ikan gurami dan ikan nila biasanya hidup bergerombol, sehingga nelayan di Danau Maninjau juga menangkapnya dengan jala dan jaring langli. Ikan limbek dan gurami banyak ditangkap di outlet Danau Maninjau karena menyukai air berarus (Roesma, 2013; Nontji, 2016).

\subsection{Status Pencemaran Lokasi Penangkapan dan Ikan Hasil Tangkapan}

Pencemaran lokasi penangkapan dan ikan hasil tangkapan dapat terjadi di Danau Maninjau, karena adanya limbah/bahan pencemar potensial dari aktivitas ekonomi. Berdasarkan skala pengusahaannya, aktivitas ekonomi tersebut dibagi menjadi dua, yaitu (a) skala industri, seperti PLTA, wisata danau, hotel dan restoran, serta (b) skala domestik, seperti pemukiman, perikanan KJA, dan pertanian. Tabel 2, menyajikan hasil identifikasi sumber limbah dan potensi dampak terhadap kegiatan penangkapan ikan.

Tabel 2. Sumber limbah dan potensi dampak terhadap kegiatan penangkapan ikan

\begin{tabular}{|c|c|c|c|c|}
\hline \multirow{2}{*}{ No. } & \multirow{2}{*}{ Sumber Limbah } & \multicolumn{2}{|c|}{ Dampak Terhadap Lokasi Penangkapan Ikan } & \multirow{2}{*}{$\begin{array}{c}\text { Pencemaran Pada } \\
\text { Ikan Yang Tertangkap }\end{array}$} \\
\hline & & Penyempitan & Jenis Pencemaran & \\
\hline \multirow[t]{4}{*}{1.} & Skala industri & & & \\
\hline & - PLTA & $\sqrt{ }$ & $\begin{array}{l}\sqrt{ } \text { (peningkatan suhu, arus } \\
\quad \text { deras) }\end{array}$ & $\sqrt{ }$ \\
\hline & - Wisata danau & $\sqrt{ }$ & $\begin{array}{l}\sqrt{ } \text { (gangguan estetika, } \\
\text { sampah) }\end{array}$ & $\sqrt{ }$ \\
\hline & - Hotel dan Restoran & & $\begin{array}{l}\sqrt{ } \text { (limbah padat, limbah } \\
\quad \text { cair, bau, sisa kemasan) }\end{array}$ & $\sqrt{ }$ \\
\hline \multirow[t]{4}{*}{2.} & Skala domestik & & & \\
\hline & - Pemukiman & & $\begin{array}{l}\sqrt{ } \text { (limbah padat, limbah } \\
\text { cair, bau) }\end{array}$ & $\sqrt{ }$ \\
\hline & - Perikanan KJA & $\sqrt{ }$ & $\begin{array}{l}\sqrt{ }(\text { limbah amoniak, } \\
\text { sedimentasi) }\end{array}$ & $\sqrt{ }$ \\
\hline & - Pertanian & & $\begin{array}{l}\sqrt{ }(\text { sampah organik, sisa } \\
\text { pestisida) }\end{array}$ & $\sqrt{ }$ \\
\hline
\end{tabular}

Berdasarkan Tabel 2, PLTA, wisata danau, dan perikanan KJA berpotensi menyebabkan penyempitan lokasi penangkapan, mencemari perairan sekitar lokasi penangkapan, serta mencemari ikan hasil tangkapan. Hal ini terjadi karena ketiga aktivitas ekonomi tersebut dilakukan di areal danau, dan limbah yang ditimbulkannya langsung terbuang ke danau. Pemukiman, pertanian, serta hotel dan restoran juga menjadi penyumbang penting terhadap pencemaran lokasi penangkapan dan ikan hasil tangkapan di Danau Maninjau. Menurut Su et al. (2016) dan Mustaruddin
(2012), limbah pemukiman, hotel dan restoran dapat berupa sampah, deterjen, kebauan, amoniak, dan bekas pengikisan/potongan bahan logam. Kegiatan pertanian, umumnya menghasilkan limbah dalam bentuk bau, logam, dan sampah organik seperti daun, rerumputan, ranting, dan potongan kayu (Samuel dan Adiansyah, 2016; Wargasasmita, 2002). Tabel 3 menyajikan hasil analisis status pencemaran lokasi penangkapan dan ikan hasil tangkapan yang disebabkan oleh limbah tersebut di Danau Maninjau. 
Tabel 3. Status pencemaran lokasi penangkapan dan ikan hasil tangkapan

\begin{tabular}{|c|c|c|c|c|c|}
\hline \multirow{2}{*}{ No. } & \multirow{2}{*}{ Parameter } & \multirow{2}{*}{ Kriteria Mutu } & \multicolumn{2}{|c|}{ Lokasi Sampling } & \multirow{2}{*}{ Status } \\
\hline & & & $\mathbf{L 1}^{\mathbf{c}}$ & $\mathbf{L} 2^{\mathbf{c}}$ & \\
\hline \multirow[t]{11}{*}{1.} & $\begin{array}{l}\text { Perairan sekitar lokasi } \\
\text { penangkapan ikan }\end{array}$ & & & & \\
\hline & - $\mathrm{pH}$ & $6-9^{a}$ & 7,2 & 7,5 & baik \\
\hline & - $\quad \mathrm{DO}(\mathrm{ppm})$ & $>3^{\mathrm{a}}$ & 5,2 & 4,6 & baik \\
\hline & - Amoniak (mg/l) & tidak ada (-) & 0,282 & 0,311 & tercemar \\
\hline & - Kebauan & alami & alami & alami & baik \\
\hline & - Sampah/kotoran padat & tidak ada (-) & - & + & agak tercemar \\
\hline & - $\quad$ Deterjen (ug/l) & $<200^{\mathrm{a}}$ & 85 & 112 & baik \\
\hline & - Warna (CU) & $<50^{\mathrm{a}}$ & 27 & 38 & baik \\
\hline & - $\quad$ Suhu $\left({ }^{\circ} \mathrm{C}\right)$ & alami $^{\mathrm{a}}$ & 29,4 & 28,2 & baik \\
\hline & - $\quad$ Logam Cd (ppm) & $<0,01^{\mathrm{a}}$ & 0,02 & 0,03 & tercemar \\
\hline & - $\quad$ Logam Hg (ppm) & $<0,002^{\mathrm{a}}$ & 0,002 & 0,007 & tercemar \\
\hline \multirow[t]{6}{*}{2.} & Ikan hasil tangkapan & & & & \\
\hline & - Logam Cd (ppm) & & & & \\
\hline & - $\quad$ Logam Hg (ppm) & $<0,1^{\mathrm{b}}$ & 0,04 & 0,04 & baik \\
\hline & - Kebauan & $<0,5^{b}$ & 0,3 & 0,3 & baik \\
\hline & - Kekotoran insang & alami & alami & alami & baik \\
\hline & - Kelendiran sisik & tidak ada (-) & - & + & agak tercemar \\
\hline
\end{tabular}

Berdasarkan Tabel 3, lokasi penangkapan ikan di Danau Maninjau telah tercemar oleh amoniak, sampah, logam $\mathrm{Cd}$, dan logam $\mathrm{Hg}$. Hal ini bersesuaian dengan penelitian Sari et al. (2015) dan Saputra et al. (2010) yang menunjukkan bahwa amoniak telah menyebabkan degradasi kualitas air Danau Maninjau, tercemar logam berat, dimana $\mathrm{Hg}$ merupakan logam yang mencemari paling dominan pada air danau. Untuk parameter lainnya, seperti pH, DO, kebauan, deterjen, warna, dan suhu masih tergolong baik. Kadar amoniak yang tinggi diduga berasal dari sisa pakan pada perikanan KJA, limbah pemukiman, serta limbah hotel dan restoran. Menurut DKP Kabupaten Agam (2015) dan Asnil et al. (2013), perikanan KJA memberikan sumbangan 393,22 ton/tahun limbah dalam bentuk amoniak dan posfat ke Danau Maninjau. Limbah pemukiman dan restoran, seperti sisa nasi, sayuran, dan lauk juga menghasilkan kadar amoniak yang tinggi terutama bila dibuang dalam keadaan busuk (Su et al. 2016; Mo et al. 2014). Sampah yang banyak ditemukan di Danau Maninjau diantaranya plastik bungkusan, ranting, dan potongan kayu. Sampah dalam bentuk ranting dan potongan kayu sangat mudah tersangkut pada alat tangkap serta menjadi penyebab dominan jaring robek dan tali pancing putus (Sumaila et al. 2016; Gundo 2010).

Kadar logam $\mathrm{Cd}$ dan $\mathrm{Hg}$ yang tinggi pada lokasi penangkapan diduga berasal dari limbah pemukiman, hotel, restoran, dan pengikisan komponen bebatuan di areal pertanian. Penggunaan peralatan dapur yang terbuat dari logam campuran merupakan penyumbang utama pencemaran $\mathrm{Cd}$. Logam berat sangat berbahaya karena dapat mendegradasi kesuburan lokasi penangkapan ikan dan menyebabkan kematian pada beberapa jenis ikan (Noel et al. 2016; Jalali et al. 2015). Ikan rinuak, ikan bada, dan ikan rayo sangat rentan terhadap logam berat dan bahan pencemar toksik lainnya (Suryono dan Lukman, 2016; BP2KSI, 2016).
Ikan hasil tangkapan juga sedikit tercemar dalam bentuk insang kotor $(18,75 \%)$, diduga sebagai dampak dari tingginya amoniak dan komponen sampah di lokasi penangkapan. Menurut Mo et al. (2014) dan Asnil et al. (2013), amoniak dapat membentuk koagulan dengan padatan tersuspensi, sehingga meningkatkan daya kotor perairan di sekitar lokasi penangkapan ikan.

\subsection{Pola Pencemaran Penangkapan Ikan Akibat Limbah Aktivitas Ekonomi}

Kegiatan penangkapan ikan merupakan mata pencaharian utama dari nelayan tradisional air tawar di sekitar Danau Maninaju (DKP Kabupaten Agam, 2015). Bila limbah yang masuk ke danau tidak bisa ditekan, maka dapat mengganggu lokasi penangkapan dan produksi ikan yang dilakukan nelayan tersebut. Hasil analisis keterkaitan lokasi penangkapan ikan dengan limbah yang masuk ke danau disajikan pada Tabel 4.

Berdasarkan Tabel 4, semua aktivitas ekonomi baik yang berskala industri maupun domestik yang limbahnya dibuang ke danau, mengganggu lokasi penangkapan ikan. Hal ini ditunjukkan oleh nilai PC yang negatif. Namun yang signifikan dan intensif interaksi gangguannya terhadap lokasi penangkapan ikan adalah PLTA, wisata danau, pemukiman, dan perikanan KJA. Gangguan krusial kegiatan wisata danau dan PLTA terhadap lokasi penangkapan ikan adalah menyempitnya wilayah perairan yang dapat dimanfaatkan oleh nelayan untuk mengoperasikan alat tangkap. Menurut Porter et al. (2015) dan Pascoe et al. (2014), wisata danau dalam bentuk berenang, menyelam, dan berlayar mengganggu pengoperasian alat tangkap jaring (jaring langli, bagan bada, dan jala). Sterilisasi wilayah perairan sekitar PLTA juga mengganggu pengoperasian lukah dan perangkap 
lainnya, karena tidak bisa lagi dipasang pada air yang berarus dekat PLTA. Akibatnya, hasil tangkapan ikan dasar terutama ikan limbek menjadi berkurang. Breen et al. (2016) dan Rahman (2016) menyatakan bahwa pengaruh eksternal sering tidak diperhatikan dalam pengukuran produktivitas alat tangkap, padahal dampaknya bisa sangat dominan.

Tabel 4. Interaksi lokasi penangkapan ikan dengan limbah aktivitas ekonomi

\begin{tabular}{cllccc}
\hline No. & Interaksi & \multicolumn{2}{c}{ Parameter } & \multicolumn{2}{c}{ Limbah Aktivitas Ekonomi } \\
\hline 1. & Skala industri & & PLTA $(\mathrm{X} 1)$ & Wisata Danau $(\mathrm{X} 2)$ & Hotel\&Restoran $(\mathrm{X} 3)$ \\
\hline \multirow{2}{*}{$\begin{array}{l}\text { Lokasi } \\
\text { penangkapan }\end{array}$} & Pearson Correlation $(\mathrm{PC})$ & $-0,530$ & $-0,401$ & $-0,278$ \\
\cline { 2 - 6 } & Probability $(\mathrm{P})^{*}$ & 0,003 & 0,028 & 0,137 \\
\hline \multirow{2}{*}{ Skala domestik } & & Pemukiman $(\mathrm{X} 4)$ & Perikanan KJA (X5) & Pertanian (X6) \\
\hline \multirow{2}{*}{$\begin{array}{l}\text { Lokasi } \\
\text { penangkapan }\end{array}$} & Pearson Correlation $(\mathrm{PC})$ & $-0,590$ & $-0,619$ & $-0,202$ \\
\cline { 2 - 5 } & Probability $(\mathrm{P})^{*}$ & 0,001 & 0,000 & 0,283 \\
\hline
\end{tabular}

Keterangan: *significant at the 0.05 level (2-tailed).

Perikanan KJA signifikan mengganggu lokasi penangkapan ikan, yang ditunjukkan oleh nilai $\mathrm{PC}=$ 0,619 (keeratan kuat) dan $\mathrm{P}=0,000$. Hal ini bisa jadi karena selain alat tangkap tidak bisa dioperasikan di areal KJA, juga keberadaan perikanan KJA telah menyebabkan pencemaran amoniak yang tinggi (Tabel 3). Pengoperasian bagan bada yang umumnya dilakukan di perairan dangkal mulai tertekan oleh penyebaran KJA di banyak tempat. Sedangkan untuk amoniak, kadarnya yang tinggi menyebabkan bau busuk, pengentalan padatan tersuspensi, dan pada ambang batas tertentu dapat secara dratis menurunkan konsentrasi oksigen terlarut (DO), karena adanya proses oksidasi amoniak dan peningkatan belerang sulfida. Hal ini diduga sebagai penyebab utama kematian ikan massal dalam 8 tahun terakhir, serta fluktuasi produksi ikan di Danau Maninjau (Said et al., 2011).

Secara keseluruhan, pola pencemaran lokasi penangkapan ikan $\left(\mathrm{Y}_{1}\right)$ oleh limbah PLTA $\left(\mathrm{X}_{1}\right)$, wisata danau $\left(\mathrm{X}_{2}\right)$, pemukiman $\left(\mathrm{X}_{4}\right)$, dan perikanan $\mathrm{KJA}\left(\mathrm{X}_{5}\right)$ dapat dirumuskan dengan model regresi : $\mathrm{Y}_{1}=0,220 \mathrm{X}_{1}+0,085 \mathrm{X}_{2}+0,227 \mathrm{X}_{4}+0,204 \mathrm{X}_{5}-4,540 \quad(\mathrm{R}=$ $0,754, P=0,000)$. Model regresi tersebut dapat dipercaya karena mempunyai nilai $\mathrm{P}<0,05$, yaitu 0,000 . Disamping itu, model regresi juga menjelaskan bahwa 75,4 \% pencemaran lokasi penangkapan ikan di Danau Maninjau diakibatkan oleh limbah PLTA, wisata danau, pemukiman, dan perikanan KJA. Hasil analisis tersebut sesuai dengan temuan Nontji (2016) yang menyatakan perikanan KJA dan pemukiman sebagai sumber limbah dengan intensitas buangan paling tinggi ke Danau Maninjau. Sedangkan untuk PLTA dan wisata danau mempunyai potensi dampak yang lebih beragam, yaitu selain dampak mencemari juga menyebabkan penyempitan lokasi penangkapan ikan (Tabel 2). Asnil et al. (2013) menyatakan bahwa penyempitan lokasi penangkapan ikan sering dikeluhkan oleh nelayan di Danau Maninjau karena secara langsung mengganggu produksi ikan. Gambar 3 menunjukkan kondisi produksi ikan yang berasal dari kegiatan penangkapan ikan di Danau Maninjau pada periode tahun 2012-2015.

Berdasarkan Gambar 3, produksi ikan didominasi oleh ikan nila yang setiap tahunnya mencapai rata-rata $5.185,3$ ton atau 35,7 \% dari total produksi. Hal ini dapat dipahami, karena ikan nila relatif tahan terhadap dampak pencemaran (Asnil et al. 2013 dan Roesma 2013). Produksi yang juga dominan adalah ikan bada yang setiap tahunnya mencapai rata-rata $3.497,0$ ton atau $24,1 \%$ dari total produksi. Namun demikian, produksi ikan tersebut cenderung turun dari tahun ke tahun dan terganggu oleh limbah aktivitas ekonomi di sekitar Danau Maninjau. Interaksi produksi dengan limbah aktivitas ekonomi ditunjukkan oleh hasil analisis Tabel 5.

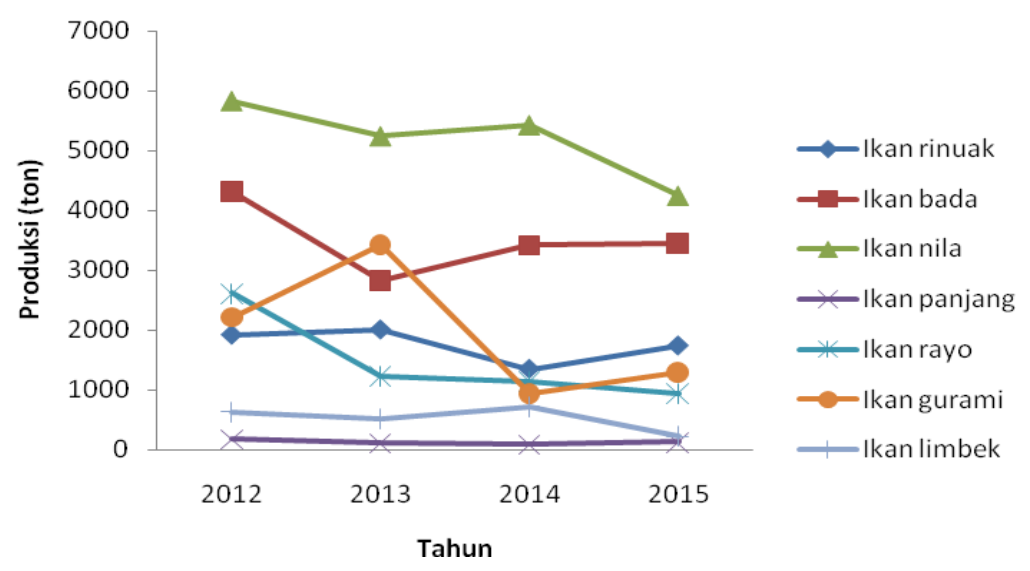

.Gambar 3. Produksi ikan yang berasal dari kegiatan penangkapan periode tahun 2012-2015 
Tabel 5. Interaksi produksi ikan dengan limbah aktivitas ekonomi

\begin{tabular}{|c|c|c|c|c|c|}
\hline No. & Interaksi & Parameter & & Limbah Aktivitas E & \\
\hline \multirow[t]{3}{*}{1.} & Skala industri & & PLTA (X1) & Wisata Danau (X2) & Hotel\&Restoran (X3) \\
\hline & Del & Pearson Correlation (PC) & $-0,261$ & $-0,177$ & $-0,461$ \\
\hline & Produks1 1kan & Probability $(\mathrm{P})^{*}$ & 0,164 & 0,351 & 0,010 \\
\hline \multirow[t]{3}{*}{2.} & Skala domestik & & Pemukiman (X4) & Perikanan KJA (X5) & Pertanian (X6) \\
\hline & Produksi ikan & Pearson Correlation (PC) & $-0,586$ & $-0,759$ & $-0,182$ \\
\hline & & Probability $(\mathrm{P})^{*}$ & 0,001 & 0,000 & 0,336 \\
\hline
\end{tabular}

Keterangan: *significant at the 0.05 level (2-tailed).

Berdasarkan Tabel 5, limbah aktivitas ekonomi yang signifikan dan intensif interaksi gangguannya terhadap produksi ikan di Danau Maninjau adalah limbah hotel dan restoran, pemukiman, dan perikanan KJA. Nilai korelasi (PC) dan probability (P) dari limbah ketiga aktivitas ekonomi tersebut adalah berturut-turut 0,461(keeratan sedang) dan 0,000, -0,586 (keeratan kuat) dan 0,001 , serta $-0,759$ (keeratan sangat kuat) dan 0,000 . Pola pencemaran ikan hasil tangkapan yang diwakili oleh penurunan produksi ikan $\left(\mathrm{Y}_{2}\right)$ akibat limbah hotel dan restoran $\left(\mathrm{X}_{3}\right)$, pemukiman $\left(\mathrm{X}_{4}\right)$, dan perikanan $\mathrm{KJA}\left(\mathrm{X}_{5}\right)$ dapat dirumuskan dengan model regresi: $\mathrm{Y}_{2}=1,195 \mathrm{X}_{3}+2,152 \mathrm{X}_{4}+5,140 \mathrm{X}_{5}-41,664(\mathrm{R}=$ $0,792, \quad P=0,000)$. Berdasarkan model tersebut, pengaruh pembuangan limbah dari ketiga aktivitas ekonomi terhadap penurunan produksi termasuk besar $(79,2 \%)$ dan signifikan. Hal ini kemungkinan karena limbah yang dihasilkan oleh ketiga aktivitas ekonomi umumnya bersifat toksik, seperti logam $\mathrm{Cd}, \operatorname{logam} \mathrm{Hg}$, dan amoniak, sehingga ikan-ikan tertentu yang rentan akan mati sebelum sempat ditangkap. Hal ini juga sesuai dengan hasil penelitian Sugiarti et al. (2016) dan Samuel dan Adiansyah (2016) yang menyatakan bahwa kualitas perairan dan toksisitas limbah berpengaruh besar terhadap naik turunnya produksi ikan, serta mempengaruhi status trofik. Sedangkan menurut Noel et al. (2013) dan Lin et al. (2007), limbah yang bersifat toksik mempunyai dampak yang revolusioner dan masif terhadap penurunan produksi ikan, jauh mengalahkan penyebab teknis seperti upaya penangkapan berlebih, alat tangkap tidak selektif, dan alat pendukung yang tidak sesuai. Produksi ikan rinuak dan ikan rayo yang rendah (Gambar 3), bisa jadi disebabkan oleh sifatnya yang rentan terhadap keberadaan bahan pencemar toksik tersebut.

\section{Kesimpulan}

Alat tangkap yang banyak digunakan nelayan di Danau Maninjau adalah jaring langli, bagan bada, pancing, dan jala. Hasil tangkapan utama dari : (a) jaring langli adalah ikan nila dan ikan bada, (b) bagan bada adalah ikan bada dan ikan rinuak, (c) pancing adalah ikan gurami dan ikan limbek, serta (d) jala adalah ikan nila dan ikan gurami. Lokasi penangkapan ikan di Danau Maninjau tercemar oleh amoniak, sampah, logam Cd dan logam Hg. Ikan hasil tangkapan sedikit terkena dampak pencemaran, yaitu berupa insang kotor $(18,75 \%)$. Secara signifikan, lokasi penangkapan ikan terganggu oleh limbah PLTA $\left(\mathrm{X}_{1}\right)$, wisata danau $\left(\mathrm{X}_{2}\right)$, pemukiman $\left(\mathrm{X}_{4}\right)$, serta perikanan KJA $\left(\mathrm{X}_{5}\right)$. Pola pencemaran lokasi penangkapan ikan $\left(\mathrm{Y}_{1}\right)$ oleh limbah keempat aktivitas ekonomi tersebut dirumuskan dengan $\mathrm{Y}_{1}=$ $0,220 \mathrm{X}_{1}+0,085 \mathrm{X}_{2}+0,227 \mathrm{X}_{4}+0,204 \mathrm{X}_{5}-4,540$, dimana pemukiman $\left(\mathrm{X}_{4}\right)$ paling dominan. Produksi ikan hasil tangkapan terganggu signifikan oleh limbah dari hotel dan restoran $\left(\mathrm{X}_{3}\right)$, pemukiman $\left(\mathrm{X}_{4}\right)$, serta perikanan KJA $\left(\mathrm{X}_{5}\right)$. Pola pencemaran ikan hasil tangkapan yang diwakili oleh penurunan produksi ikan $\left(\mathrm{Y}_{2}\right)$ dirumuskan dengan $\mathrm{Y}_{2}=1,195 \mathrm{X}_{3}+2,152 \mathrm{X}_{4}+5,140 \mathrm{X}_{5}$ 41,664. Berdasarkan persamaan tersebut, kegiatan perikanan $\mathrm{KJA}\left(\mathrm{X}_{5}\right)$ berpotensi mencemari ikan hasil tangkapan paling dominan.

\section{Daftar Pustaka}

[1] [BP2KSI] Balai Penelitian Pemulihan dan Konservasi Sumberdaya Ikan, 2016. Hasil kajian cepat setelah kematian ikan massal di Danau Maninjau, Kabupaten Agam, Provinsi Sumatera Barat. BP2KSI. [terhubung berkala]. http://bp2ksi.litbang.kkp.go.id/index.php [21 Desember 2016].

[2] [DKP] Dinas Kelautan dan Perikanan Kabupaten Agam, 2015. Potensi Perikanan Danau Maninjau. DKP Kabupaten Agam, Lubuk Basung.

[3] Asnil, K. Mudikdjo, S. Hardjoamidjojo S, A. Ismail, 2013. Analisis kebijakan pemanfaatan sumberdaya danau yang berkelanjutan (Studi kasus Danau Maninjau, Sumatera Barat). Jurnal Pengelolaan Sumberdaya Alam dan Lingkungan. 3(1), pp. 1-9.

[4] Breen, M., N. Graham, M. Pol, P. He, D. Reid, P. Suuronen, 2016. Selective fishing and balanced harvesting. Journal of Fisheries Research. 184(1), pp. 2-8.

[5] Fahrul, M. F., 2007. Metode Sampling Bioekologi. Bumi Aksara, Jakarta

[6] Fernández, N., M. Fernández-Boán, P. Verísimo, J. Freire, 2013. Assessing the spatial variability, level and source of organic chemical contaminants in bivalve fishing grounds on the Galician coast. Marine Pollution Bulletin. 71(1), pp. 291301.

[7] Field, A., 2013. Discovering statistics using IBM SPSS statistics. $4^{\text {th }}$ Edition. SAGE Publications, London (UK).

[8] Gundo, M. T., 2010. Daerah penangkapan dan status alat tangkap ikan rono (Xenopoecilus oophorus) di Danau Poso. Jurnal MLS. 3(1), pp. 33-37.

[9] Hastings, K., K. L. Ryan, 2017. Differences in perception of a newly created Marine Park in south-west Western Australia by boat-based recreational fishers and the broader community. Marine Policy. 77(1), pp. 65-77

[10] Jalali, M. A., D. Ierodiaconou, J. Monk, H. Gorfine, A. Rattray, 2015. Predictive mapping of abalone fishing grounds using remotely-sensed LiDAR and commercial catch data. Journal of Fisheries Research. 169(1), pp. 26-36.

[11] Lin, B., C. Y. Lin, T. C. Jon, 2007. Investigation of strategies to improve the recycling effectiveness of waste oil from fishing vessels. Journal of Marine Policy. 31(4), pp. 415-420. 
[12] Maina, I., S. Kavadas, S. Katsanevakis, S. Somarakis, G. Tserpes, S. Georgakarakos, 2016. A method-logical approach to identify fishing grounds: A case study on Greek trawlers. Journal of Fisheries Research. 183(1), pp. 326-339.

[13] Mo, W. Y., Z. Cheng, W. M. Choi, Y. B. Man, Y. Liu, M. H. Wong, 2014. Application of food waste based diets in polyculture of low trophic level fish: Effects on fish growth, water quality and plankton density. Marine Pollution Bulletin. 85(2), pp. 803-809.

[14] Mustaruddin, 2012. Pola Pencemaran $\mathrm{Hg}$ dan $\mathrm{Pb}$ pa-da fishing ground dan ikan yang tertangkap nelayan: Studi kasus di Teluk Jakarta. Jurnal Bumi Lestari. 13(2), pp. 214-224.

[15] Noel, L, R. Chekri, S. Millour, M. Merlo, J. C. Jean-Charles Leblanc, T. Guerina, 2013. Distribution and relationships of $\mathrm{As}, \mathrm{Cd}, \mathrm{Pb}$ and $\mathrm{Hg}$ in freshwater fish from five French fishing areas. Journal of Chemosphere. 90(6), pp. 1900-1910.

[16] Nontji, A. 2016. Danau Maninjau. Lembaga Ilmu Pengetahuan Indonesia (LIPI), Jakarta, $8 \mathrm{hlm}$

[17] Pascoe, S., A. Doshi, Q. Dell, M. Tonks, R. Kenyon, 2014. Economic value of recreational fishing in Moreton Bay and the potential impact of the marine park rezoning. Journal of Tourism Management. 41(1), pp. 53-63.

[18] Peraturan Pemerintah Republik Indonesia, 2001. Lampiran Peraturan Pemerintah Republik Indonesia Nomor 82 Tahun 2001. Tanggal 14 Desember 2001.

[19] Porter, B. A., M. B. Orams, M. Lück, 2015. Surf-riding tourism in coastal fishing communities: A comparative case study of two projects from the Philippines. Ocean \& Coastal Management. 116(1), pp. 169-176.

[20] Rahman, M., 2016. Dampak pengoperasian alat penangkap ikan terhadap sumberdaya ikan Rawa Danau Bangkau. Jurnal Fish Scientiae. 2(4), pp. 131-140.

[21] Roesma, D. I., 2013. Evaluasi Keanekaragaman Spesies Ikan Hasil Tangkapan di Danau Maninjau. Dalam: Prosiding Semirata; $8 \mathrm{hlm}$. FMIPA Universitas Lampung, Bandar Lampung.

[22] Said D., S. Triyanto, Lukman, Sutrisno, A. Hamdani, 2011. Aspek biologi ikan bada (Rasbora argyrotaenia) di Danau Maninjau, Sumatera Barat. Dalam: Prosiding Forum Nasional Pemacuan Sumber Daya Ikan III; 2011 Oktober 18. Kementerian Kelautan dan Perikanan, Jakarta.
[23] Samuel, V. Adiansyah, 2016. Kualitas air, status tro-fik dan potensi produksi ikan Danau Diatas, Sumatera Barat. Jurnal Penelitian Perikanan Indonesia. 22(1), pp. 83-94.

[24] Saputra, A., A.B. Prasetio, I.N. Radiarta, 2010. 2010 Distribusi logam berat dalam air dan sedimen di Perairan Danau Maninjau di Provinsi Sumatera Barat. Dalam: Prosiding Forum Inovasi Teknologi Akuakultur; 2010 September 14. Badan Penelitian dan Pengembangan Kelautan dan Perikanan, Kementerian Kelautan dan Perikanan, Jakarta.

[25] Sari, P.M., Y. Darvina, Hamdi, 2016. Degradasi kualitas fisis air Danau Maninjau terhadap variasi jarak dan jumlah keramba. Pillar of Physics. 6(1), pp. 41-48.

[26] Sarwono, J., 2006. Analisis data penelitian menggunakan SPSS. Penerbit ANDI, Yogyakarta.

[27] Setiyawan, A., L. Sadiyah, S. Samsuddin, 2016. Faktor-faktor penting yang mempengaruhi CPUE (catch per unit effort) perikanan huhate berbasis di Bitung. Jurnal Penelitian Standar Nasional Indonesia. Tanggal 31 Desember 2009.

[28] Su, M. M., G. Wall, M. Jin, 2016. Island livelihoods: Fishing and Tourism at Long Islands, Shandong Province, China. Ocean and Coastal Management. 122(1), pp. 20-29.

[29] Sugiarti, S. Hariyadi, S. H. Nasution, 2016. Keterkaitan antara kualitas air dengan hasil tangkapan ikan di Muara Sungai Teluk Banten, Provinsi Banten. LIMNOTEK Perairan Darat Tropis di Indonesia. 23(1), pp. 1-16.

[30] Sumaila, U. R., C. Bellmann, A. Tipping, 2016. Fishing for the Future: An Overview of Challenges and Opportunities. Journal of Marine Policy. 69(1), pp. 173-180.

[31] Suryono, T., Lukman, 2016. Pengaruh kualitas perairan terhadap komposisi perifiton di Danau Maninjau. LIMNOTEK Perairan Darat Tropis di Indonesia. 23(1), pp. 33 $-43$.

[32] Susanto, H., 1989. Budidaya ikan gurame. Penebar Swadaya. Jakarta.

[33] Wargasasmita, S., 2002. Ikan air tawar endemik Sumatra yang terancam punah. Jurnal Iktiologi Indonesia. 2(1), pp. 41-49.

[34] Zydelis, R., C. Small, G. French, 2013. The incidental catch of seabirds in gillnet fisheries: A global review. Journal of Biological Conservation. 162(1), pp. 76-88. 